\title{
Secularity, abortion, assisted dying and the future of conscientious objection: modelling the relationship between attitudes
}

\author{
Morten Magelssen ${ }^{1 *}$ (D), Nhat Quang Le $\mathrm{L}^{2}$ and Magne Supphellen ${ }^{3}$
}

\begin{abstract}
Background: Controversies arise over abortion, assisted dying and conscientious objection (CO) in healthcare. The purpose of the study was to examine the relationship between attitudes towards these bioethical dilemmas, and secularity and religiosity.

Method: Data were drawn from a 2017 web-based survey of a representative sample of 1615 Norwegian adults. Latent moderated structural equations modelling was used to develop a model of the relationship between attitudes.

Results: The resulting model indicates that support for abortion rights is associated with pro-secular attitudes and is a main "driver" for support for assisted dying and opposition to conscientious objection.

Conclusions: This finding should be regarded as a hypothesis which ought to be tested in other populations. If the relationship is robust and reproduced elsewhere, there are important consequences for CO advocates who would then have an interest in disentangling the debate about CO from abortion; and for health systems who ought to consider carefully how a sound policy on CO can safeguard both patient trust in the services and the moral integrity of professionals. It is suggested that if religiosity wanes and pro-secular and pro-abortion attitudes become more widespread, support for CO might decline, putting into question whether present policies of toleration of conscientious refusals will remain acceptable to the majority.
\end{abstract}

Keywords: Abortion, Assisted dying, Conscientious objection, Euthanasia, Public attitudes

\section{Background}

Conscientious objection $(\mathrm{CO})$, where a healthcare professional refuses to participate in healthcare service provision for moral or religious reasons, is likely to become an increasingly prominent dilemma in jurisdictions and healthcare systems in the Western world [1]. With increasing medical possibilities come more controversial procedures and moral grey zones, including but not limited to assisted reproductive techniques, genetic engineering, therapy based on embryo-destructive research, and prenatal screening. Such dilemmas are likely to give

\footnotetext{
* Correspondence: magelssen@gmail.com

${ }^{1}$ Centre for Medical Ethics, Institute of Health and Society, University of Oslo, Pb. 1130 Blindern, N-0318 Oslo, Norway

Full list of author information is available at the end of the article
}

rise to moral qualms among subsets of practitioners, and, for some, to refusals to participate in specific procedures: conscientious objection. Such novel cases of $\mathrm{CO}$ would then supplement the traditional cases of refusals to participate in abortions, limitation of life-prolonging treatment, or assisted dying (euthanasia and physicianassisted suicide) [1].

Trust is a prime resource necessary for health provider systems to thrive [2-5]. Policies for tolerance for conscientious objection might protect public trust, yet might also damage trust, depending on public perception. The $\mathrm{CO}$ of subsets of employees might therefore lead to difficult balancing acts for health systems: On the one hand, health systems must protect the professional autonomy and moral integrity of employees, and must respect any

(c) The Author(s). 2019 Open Access This article is distributed under the terms of the Creative Commons Attribution 4.0 International License (http://creativecommons.org/licenses/by/4.0/), which permits unrestricted use, distribution, and reproduction in any medium, provided you give appropriate credit to the original author(s) and the source, provide a link to the Creative Commons license, and indicate if changes were made. The Creative Commons Public Domain Dedication waiver (http://creativecommons.org/publicdomain/zero/1.0/) applies to the data made available in this article, unless otherwise stated. 
statutory rights for $\mathrm{CO}$ to be tolerated in specific situations and on specific conditions. On the other hand, health systems must be seen to preserve ease and equality of access to safe, timely and legal healthcare services in a non-discriminatory fashion. If liberal policies of toleration for $\mathrm{CO}$ are perceived to be detrimental in this respect, then the health system's standing in the public's eyes is likely to be damaged and trust may be eroded.

Policies and practical arrangements for $\mathrm{CO}$ can be said to be determined through a "negotiation" between key stakeholders: the health system in question, health professionals and their professional organizations, the public, and politicians. Notably, the latter group is likely to be very receptive to the views and concerns of the public. Similarly, for the reasons noted above, health systems must also be attentive to the views of the public in order to maintain their trust. In this context, it is important to understand the population's attitudes to $\mathrm{CO}$ among health professionals.

\section{The Norwegian context}

Norway has a liberal abortion law which provides for first trimester abortion on request. Abortions are performed in public hospitals, and the law gives health professionals a right to refuse to perform or assist in abortions. The question of whether general practitioners (GPs) should be allowed to refuse to refer for abortions became the focus of extensive debate in 2012-14 [6]. Judging from the public debate the public was predominantly opposed to CO to referrals. The political upshot of the debate was a new governmental policy in which GPs no longer have any right to $\mathrm{CO}$ in cases of abortion referral, or any other situation [7]. Assisted dying is illegal in Norway, yet in public debate it is often argued that if it were to be legalized, the law would have to provide for conscientious objectors. A previous analysis of the present study showed that $69 \%$ of the citizens polled supported CO for assisted dying, whereas $37 \%$ supported the present legal right to $\mathrm{CO}$ for abortion provision, and $32 \%$ would support a similar legal right to $\mathrm{CO}$ for abortion referrals [8].

\section{Potential determinants of attitudes towards assisted dying and conscientious objection}

In studies it is a robust finding that religiosity predicts opposition to abortion and assisted dying, and support for conscientious objection [9-11]. However, the relationship between the attitudes in play is typically not studied in depth. In this study, our hypothesis was that religiosity or secularism - defined as the attitude that society should build on non-religious values - are «fundamental attitudes» that are capable of predicting attitudes towards abortion, and that this trio of attitudes religiosity, secularism, and abortion - would then predict attitudes to assisted dying and conscientious objection. For a typical citizen, then, attitudes to the two latter phenomena would to a large degree be determined by attitudes to abortion (see Fig. 1). The reasoning behind this prediction relates to the prominence of abortion as an ethical issue and the long-standing right to abortion on request. Abortion has been a recurring topic in public debates related to bioethics, often directly, yet also indirectly, as in, for instance, prenatal diagnosis. Thus, most people have established attitudes towards abortion. We therefore consider it likely that these attitudes will frame people's thinking about newer medical ethics issues, such as assisted dying and conscientious objection.

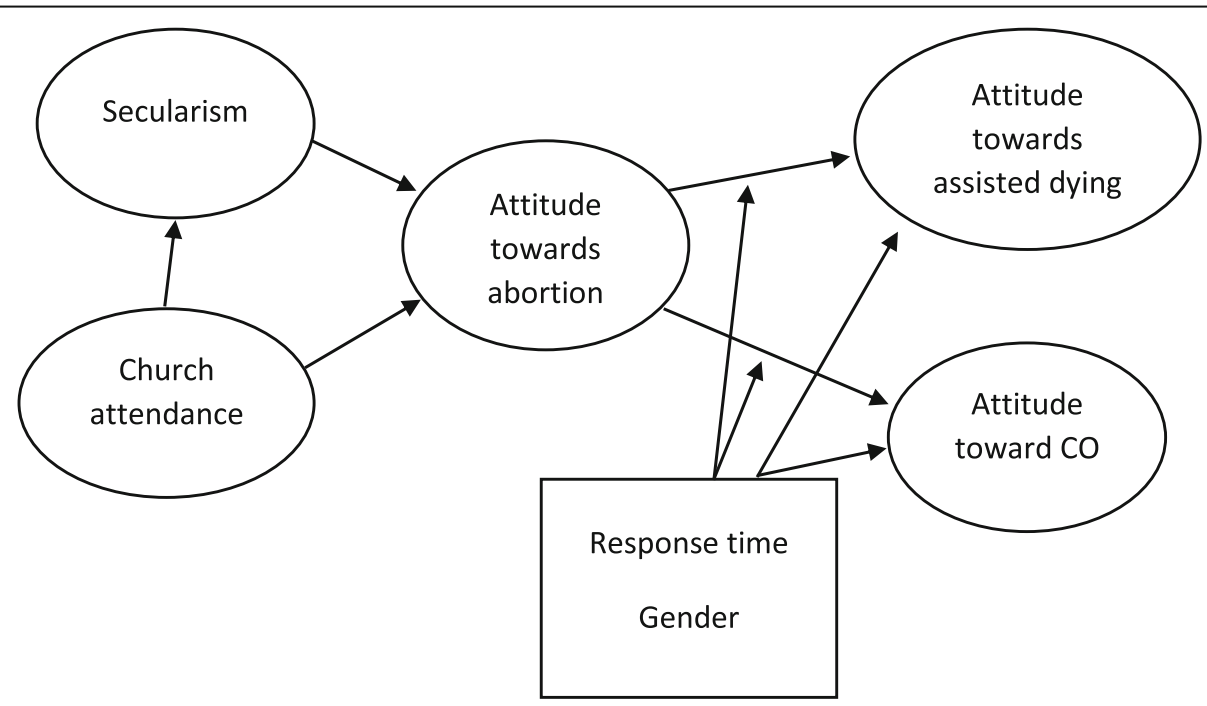

Fig. 1 Determinants of attitudes towards assisted dying and objection. Conceptual model 


\section{Methods}

\section{Data and measures}

The model was tested on data from NOBAS, the Norwegian Bioethics Attitude Survey, which assesses attitudes towards current bioethical issues in a representative sample of the population using a national web panel. In February 2017, a total of 1617 adult Norwegians completed the questionnaire (response rate: 8.5\%; see Additional file 1 for the questionnaire). After removing missing data, the final sample included 1596 observations, which is well above the recommended sample size of 200 observations for the use of structural equation modelling (SEM) [12, 13]. Responses were weighted in order to mirror the demographic profile of the population. Table 1 reports the characteristics of the weighted sample (for unweighted sample, see Additional file 1: Appendix A).

Attitude towards assisted dying, attitude towards conscientious objection, and attitude towards secularism were measured by two-item scales, while attitude towards abortion was measured by three items. All scale item questions used 5-point Likert scales anchored by 1 (fully disagree) and 5 (fully agree) (see Table 2 for all scale item questions and the relative reliability indices). Finally, we used church attendance as an indicator of religiosity and asked the respondents the following question: "How many times did you visit a church, house of prayer, mosque, synagogue etc. the last six months?" Church attendance is a common indicator of religiousness in social science research [15].

Table 1 Demographic characteristics of respondents $(N=1596)$

\begin{tabular}{lll}
\hline Characteristic & & $N(\%)$ \\
\hline Gender & Female & $796(49.8)$ \\
Age & $18-24$ & $801(50.2)$ \\
& $25-34$ & $190(11.9)$ \\
& $35-44$ & $282(17.7)$ \\
& $45-54$ & $283(17.7)$ \\
& $>54$ & $283(17.7)$ \\
Level of education & Primary school & $558(35.0)$ \\
& Upper secondary school & $74(4.6)$ \\
& College/university $\leq 3$ years & $425(26.6)$ \\
& College/university > 3 years & $643(27.2)$ \\
& Unanswered & $15(0.9)$ \\
Religious beliefs & Non-religious & $743(46.5)$ \\
& Christian & $678(42.4)$ \\
& Other religions & $26(1.6)$ \\
& Unanswered & $148(9.3)$ \\
\hline
\end{tabular}

\section{Statistical analyses}

In order to test the interaction effects between different latent constructs in this study, we used the latent moderated structural equations (LMS) method developed by Klein and Moosbrugger [16]. The LMS approach is recommended as the tests based on the kurtosis and skewness statistics have shown that our data did not satisfy the multivariate normality assumption (e.g. [16, 17]). The approach utilizes the maximum likelihood robust estimation method in order to obtain standard errors that are more precise and robust than those provided by other approaches using product indicators. In addition, as the LMS approach does not require making any new indicator for the interaction term, it avoids potential confusion about the selection and formation of new product indicators (e.g. all-pairs vs. one-pair configurations) $[18,19]$.

Because the LMS model does not provide common model fit indices such as the comparative fit index (CFI), the Tucker-Lewis index (TLI), the root mean square error of approximation (RMSEA), and the Chi-square $\left(\chi^{2}\right)$ value, we followed a two-step procedure (e.g. [16, 20]). Specifically, we first ran a structural equation model (SEM) without interaction effects (model 1). Secondly, we ran the full model including the hypothesized interaction effects (model 2). The likelihood ratio test was then used to examine whether the inclusion of the interaction effects improved the model fit. In both models, we applied the robust maximum likelihood estimation procedure using Mplus 7.2 [21].

Our results show that model 1 yields acceptable global goodness of fit indices: $\mathrm{CFI}=0.930$ and $\mathrm{TLI}=0.900$ are all above .9 [22], whereas RMSEA $=0.072$ is below the recommended cut-off value of $0.08[23,24]$ and SRMR $=0.043$ is well below 0.08 [13] (see Additional file 1: Appendix C for parameter estimates). Although the Chi-square statistic was significant $\left(\chi^{2}(44)=406.658, p\right.$-value $\left.=0.000\right)$, it is acceptable as $\chi^{2}$ value is rather sensitive to minor departure from perfect fit when the sample is very large like in our case $[22,25]$. As mentioned above, the full model with interaction (model 2) is estimated using the LMS approach so the relative fit of it versus model 1 was assessed through a likelihood ratio test comparing the log-likelihood values between the two models (see [20, 26]). Using a chi-square distribution, the likelihood ratio test proves significant $\left(\chi^{2}(4)=9.650, p\right.$-value $\left.<.05\right)$, indicating that the full model with the interaction terms is our optimal model in terms of fit. In other words, the inclusion of our studied interaction terms significantly improves our model's ability to predict the outcome variables.

One could also argue that attitude towards secularism and church attendance could directly affect attitude towards assisted dying and conscientious objection. Therefore, we tested an alternative model (model 3) in which these direct effects were included. To account 
Table 2 Measures and Reliability of Latent Variables

\begin{tabular}{|c|c|c|c|c|}
\hline Construct & Items & $C R^{a}$ & $A V E^{b}$ & a \\
\hline Attitude towards Assisted Dying & $\begin{array}{l}\text { - Assisted dying should be allowed for patients who are dying } \\
\text { - Assisted dying should be allowed for patients who have an } \\
\text { incurable chronic disease yet who are not dying }\end{array}$ & .82 & .70 & 0.81 \\
\hline Attitude towards Conscientious Objection & $\begin{array}{l}\text { - In general, healthcare professionals should be able to refrain from } \\
\text { tasks for reasons of conscience, through local agreements that } \\
\text { ensure the patient help from a colleague } \\
\text { - In general, healthcare professionals should have a statutory } \\
\text { right to refrain from tasks for reasons of conscience }\end{array}$ & .88 & .78 & 0.87 \\
\hline Attitude towards Abortion & $\begin{array}{l}\text { - In the first } 12 \text { weeks of pregnancy abortion should be available } \\
\text { on request } \\
\text { - The time limit for having an abortion should be extended to } \\
16 \text { weeks } \\
\text { - It is ethically acceptable to choose abortion because the fetus } \\
\text { has Down syndrome }\end{array}$ & .69 & .43 & 0.67 \\
\hline Attitude towards Secularism & $\begin{array}{l}\text { - Norwegian society should be secular, without influence from } \\
\text { Christianity } \\
\text { - Christianity should have greater influence on Norwegian } \\
\text { society (reversed) }\end{array}$ & .82 & .70 & 0.82 \\
\hline
\end{tabular}

Notes: ${ }^{\mathrm{a}}$ CR Composite Reliability, ${ }^{\mathrm{b}}$ AVE Average Variance Extracted. They are computed based on formulas given by Fornell, Larcker [14]

for all possibilities, we also allowed response time and gender to moderate the direct effects of attitude towards secularism and church attendance on attitudes towards assisted dying and conscientious objection. The chi-square difference test based log likelihood values show that model 3 significantly improves on model 2 in terms of fit $\left(\chi^{2}(8)=43.869, p\right.$-value $\left.<.001\right)$. Therefore, we chose model 3 to be our main model and describe the parameter estimates of this model in the next parts.

\section{Results}

As shown in Fig. 2, attitude towards abortion is strongly and positively associated with attitude towards assisted dying. The path coefficient between these constructs is high and significant $(\beta=0.521, p<0.01)$. Attitude towards abortion is negatively associated with attitude to CO. Again, the path coefficient is high and significant $(\beta=-0.414, p<0.01)$. In turn, attitude towards abortion is positively associated with attitude towards secularism $(\beta=0.321, \quad p<0.01)$ and negatively associated with

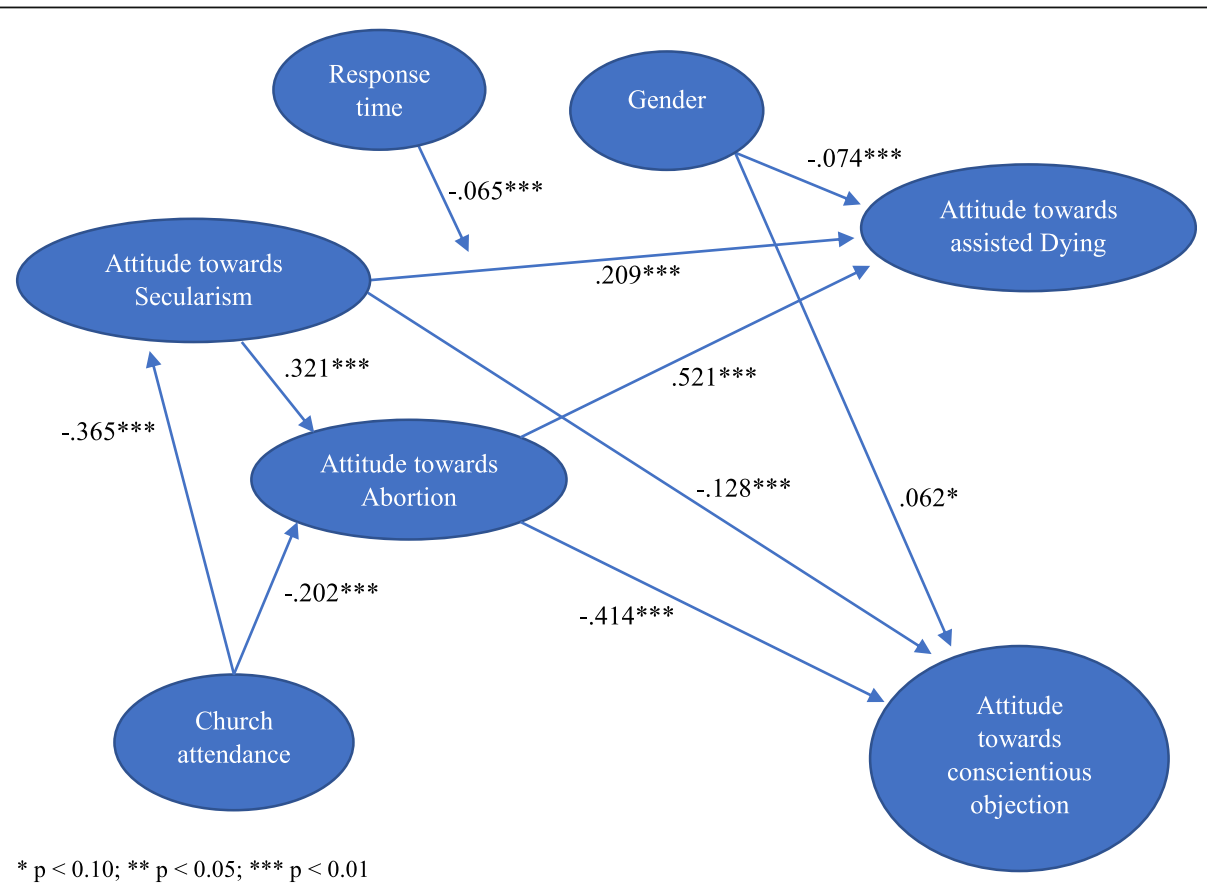

Fig. 2 Main Structural Model (Model 3) with Standardized Coefficients shows the parameter estimates among our latent variables. $p<0.10 ; *^{* *} p<$ $0.05 ;{ }^{* * *} p<0.01$ 
religiosity/church attendance $(\beta=-0.202, p<0.01)$. We also observe strongly significant direct effects of attitude towards secularism on attitudes toward assisted dying and CO. In particular, attitude towards secularism is positively associated with attitude towards assisted dying $(\beta=0.209, p<0.01)$ and negatively associated with attitude towards $\mathrm{CO}(\beta=-0.128, p<0.01)$. In addition, as expected, church attendance is negatively associated with attitude towards secularism $(\beta=-0.365, p<0.01)$. Females are somewhat more negative towards assisted dying $(\beta=-0.074, p<0.05)$ and more positive towards CO than men $(\beta=0.062, p=0.05)$.

We observe a negative interaction effect of attitude towards secularism and response time on attitude towards assisted dying $(\beta=-0.065, p<0.01)$, meaning that the (positive) relationship between attitude towards secularism and attitude towards assisted dying is somewhat weaker for respondents who spend more time on responding.

\section{Discussion}

\section{Main findings summarized}

The results show that pro-secular attitudes have a positive effect on attitudes towards assisted dying, and a negative effect on attitudes to $\mathrm{CO}$. These effects are partially and largely mediated through established attitudes towards abortion. Religiosity (church attendance) has a positive effect on acceptance of $\mathrm{CO}$ and a negative effect on acceptance of assisted dying. These effects are fully mediated by established attitudes towards secularism and abortion.

\section{Conscientious objection is seen as tied to abortion}

An important finding is that pro-secularity and support for abortion rights strongly influence attitudes towards both assisted dying and conscientious objection. In its essence, $\mathrm{CO}$ is a general phenomenon not necessarily tied to healthcare. Furthermore, it is only one of a set of dilemmas that arise for any pluralist liberal democracy concerning how the interests of moral and other minorities ought to be safeguarded. However, in the Norwegian consciousness CO appears to have become closely associated with abortion. This might be a result of recent Norwegian public debate on $\mathrm{CO}$, which has been scant except in 2012-2014 when the topic of CO to general practitioners' referrals for abortion figured very prominently on the political agenda, as mentioned above. A large majority of Norwegians favour liberal abortion rights including abortion on request in the first trimester.

\section{Conscientious objection, secularity and tolerance}

As attitudes to abortion are apparently a strong determinant of attitudes to conscientious objection, then from the perspective of a defender of conscientious objection it was quite unfortunate that the topic came to be so closely tied to abortion. Our findings support the interpretation that conscientious objection conceivably could have received greater public support if abortion had not become the "test case" in the public debate. Supporters of $\mathrm{CO}$ would do well to attempt to untie the debate from the specific topic of abortion, showing $\mathrm{CO}$ to be a more general and principled question not antithetical to abortion rights. Following the same logic, opponents of assisted dying could have an interest in disentangling the topic from abortion and from religion, whereas proponents of assisted dying could benefit from rendering assisted dying as, for instance, belonging to the same struggle for increased personal freedom as did the struggle for abortion rights.

Building on our findings a further hypothesis could be that the more secular the population becomes, the lower the tolerance for $\mathrm{CO}$ becomes. If religiosity wanes and pro-secular and pro-abortion attitudes become more widespread, support for conscientious objection might decline, putting into question whether any present policies of toleration of conscientious refusals as a practical compromise will remain acceptable to the majority. Potentially, health systems that continue to uphold a broad toleration for conscientious refusals might then endanger their standing with, and trust from, the public.

Arguably, the precise way tolerance for objectors is implemented in practice is decisive for whether it actually conflicts with patient rights and interests concerning access to care. In principle, conscientious objection might place four significant kinds of burdens on patients: there could be delays or extra expenses in receiving care; access to care could be restricted; patients could fail to receive relevant information about care choices; and the encounter with the objector or the way the objection is communicated could lead to the patient perceiving moral disapproval of their lifestyle or healthcare choices [27]. Thus, for policies of conscientious objection to be acceptable to healthcare systems and to patients, care must be taken to avoid or minimize burdens in all four domains.

Apparently, respondents who favour secularism became less positive towards assisted dying when they spent more time on responding. Although speculative, one interpretation could be that secularism for many involves a strong emphasis on individual freedom, making it likely that one's first thought about the issue of assisted dying is a strong endorsement. Counter-arguments in the complex issue of assisted dying, however, are not as strongly tied to secularism and might require more time for reflection to take fully into account.

\section{Limitations}

It is not possible to draw firm conclusions on the nature of causal relationships based solely on analyses of cross- 
sectional survey data. The best method for testing causal relationships is randomized experimentation. However, the variables involved in this study are difficult to manipulate in controlled experiments. This is why we use the second-best alternative: a version of structural equation modeling $[28,29]$. With this approach, we test how alternative models, which all make sense from a theoretical perspective, fit with the covariance structure in the dataset. We need to argue theoretically for the direction of relationships. The revised model fits very well with the covariance structure and the theoretical arguments for the relationships are reasonable. Still, there is uncertainty involved in the causal reasoning. In particular, there could be other mediators and/or moderators.

The study examines the attitudes of Norwegians and it is therefore an open question whether the same tendencies are operative in other Western countries. It would be valuable to conduct similar studies in other countries.

The low response rate means that a non-response bias cannot be excluded. However, data have been weighed in order to more closely mirror population demographics.

\section{Conclusion}

This study on the relationship between attitudes among the Norwegian public has indicated that support for abortion rights is associated with pro-secular attitudes and is a main "driver" for support for assisted dying and opposition to conscientious objection. This finding should be regarded as a hypothesis which ought to be tested in other populations. If the relationship is robust and reproduced elsewhere, there are important consequences for $\mathrm{CO}$ advocates who would then have an interest in disentangling the debate about $\mathrm{CO}$ from abortion; and for health systems who ought to consider carefully how a sound policy on CO can safeguard both patient trust in the services and the moral integrity of professionals.

\section{Supplementary information}

Supplementary information accompanies this paper at https://doi.org/10. 1186/s12910-019-0408-4.

Additional file 1: Appendix A. Demographic characteristics of respondents; Appendix B. Confirmatory Factor Analysis; Appendix C. Model 1 (without interaction terms) with Standardized Coefficients; Appendix D. The NOBAS questionnaire, translated into English.

\section{Abbreviations}

CFI: Comparative fit index; CO: Conscientious objection; LMS: Latent moderated structural equations; NOBAS: Norwegian Bioethics Attitude Survey; RMSEA: Root mean square error of approximation; SEM: Structural equation modelling; SRMR: Standardized root mean residual; TLI: TuckerLewis index

\section{Acknowledgements}

We have benefited from the comments of the two reviewers when developing our final full model.

\section{Authors' contributions}

MM and MS constructed the questionnaire. NQL and MS performed the statistical analyses. MM wrote the first draft. All authors contributed to subsequent revisions and approved the final version.

\section{Funding}

The study was performed as part of the NOBAS (Norwegian Bioethics Attitude Survey) project, which is hosted by the University of Oslo and which has received funding from four Norwegian organizations who take an interest in attitudes in bioethics: Foreningen Retten til en verdig død, Indremisjonsforbundet, Menneskeverd and Normisjon. These four organizations have had no role in design, analysis and interpretation of data, nor in the writing and publishing of the manuscript.

Availability of data and materials

The data are available on reasonable request to the first author.

\section{Ethics approval and consent to participate}

The study was evaluated by the Data Protection Official at the Norwegian Centre for Research Data (ref. 51786); according to the Norwegian system and the Norwegian Health Research Act, no further ethics approval was required. Respondents were informed about the project in the invitation email. Participation was voluntary. The respondent's completion of the questionnaire was considered as valid consent to participate; written consent was not obtained. This arrangement was in line with Norwegian regulations and accepted in the Data Protection Official's review of the study.

\section{Competing interests}

Dr. Magelssen serves as leader of the medico-ethical council of one of the funders of the NOBAS project, the organization Menneskeverd; he receives an annual remuneration. Dr. Supphellen is a board member of the organization Menneskeverd.

\section{Author details}

${ }^{1}$ Centre for Medical Ethics, Institute of Health and Society, University of Oslo, Pb. 1130 Blindern, N-0318 Oslo, Norway. ${ }^{2}$ SNF Centre for Applied Research at $\mathrm{NHH}$, Bergen, Norway. ${ }^{3}$ Department of Strategy and Management, Norwegian School of Economics, Bergen, Norway.

Received: 15 April 2019 Accepted: 6 September 2019

Published online: 18 September 2019

\section{References}

1. Wicclair MR. Conscientious objection in health care. Cambridge: Cambridge University Press; 2011.

2. Birkhäuer J, Gaab J, Kossowsky J, Hasler S, Krummenacher P, Werner C, et al. Trust in the health care professional and health outcome: a meta-analysis. PLoS One. 2017;12(2):e0170988. https://doi.org/10.1371/journal.pone.0170988.

3. Gilson L. Trust and the development of health care as a social institution. Soc Sci Med. 2003;56(7):1453-68. https://doi.org/10.1016/S0277-9536(02)00142-9.

4. Calnan MW, Sanford E. Public trust in health care: the system or the doctor? Qual Saf Health Care. 2004;13(2):92.

5. Hall MA, Dugan E, Zheng B, Mishra AK. Trust in physicians and medical institutions: what is it, can it be measured, and does it matter? Milbank Q. 2001:79(4):613-39.

6. Nordberg EM, Skirbekk H, Magelssen M. Conscientious objection to referrals for abortion: pragmatic solution or threat to women's rights? BMC Med Ethics. 2014;15:15

7. Magelssen M. How details matter morally in the debate on conscientious objection. The case of Norway. In: Frewer A, Bergemann $L$, Jäger C, editors. Jahrbuch Ethik in der Klinik 9. Würzburg: Königshausen \& Neumann; 2016. p. 343-50.

8. Barlaup AH, Landsverk ÅE, Myskja BK, Supphellen M, Magelssen M. Acceptable attitudes and the limits of tolerance: understanding public attitudes to conscientious objection in healthcare. Clin Ethics. 2019;14(3):115-21.

9. Nordstrand S, Nordstrand M, Nortvedt P, Magelssen M. Medical students' attitudes towards conscientious objection: a survey. J Med Ethics. 2014;40(9):609. 
10. Magelssen M, Supphellen M, Nortvedt P, Materstvedt LJ. Attitudes towards assisted dying are influenced by question wording and order: a survey experiment. BMC Med Ethics. 2016;17:24.

11. Emanuel EJ, Onwuteaka-Philipsen BD, Urwin JW, Cohen J. Attitudes and practices of euthanasia and physician-assisted suicide in the United States, Canada, and Europe. JAMA. 2016;316(1):79-90. https://doi.org/10.1001/jama.2016.8499.

12. Hair JF, Black WC, Babin BJ, Anderson RE. Multivariate data analysis: a global perspective. 7th ed. Upper Saddle River: Pearson Education, Inc; 2010.

13. Kline RB. Principles and practice of structural equation modeling. 3rd ed methodology in the social sciences. New York: The Guilford Press; 2010.

14. Fornell C, Larcker DF. Evaluating structural equation models with unobservable variables and measurement error. J Mark Res. 1981;18(1):39-50.

15. Gerber AS, Gruber J, Hungerman DM. Does church attendance cause people to vote? Using blue laws' repeal to estimate the effect of religiosity on voter turnout. Br J Polit Sci. 2016:46(3):481-500.

16. Klein A, Moosbrugger $\mathrm{H}$. Maximum likelihood estimation of latent interaction effects with the LMS method. Psychometrika. 2000;65(4):457-74.

17. Korschun D, Bhattacharya CB, Swain SD. Corporate social responsibility, customer orientation, and the job performance of frontline employees. J Mark. 2014;78(3):20-37.

18. Marsh HW, Wen Z, Hau K-T. Structural equation models of latent interactions: evaluation of alternative estimation strategies and Indicator construction. Psychol Methods. 2004;9(3):275-300.

19. Foldnes $\mathrm{N}$, Hagtvet KA. The choice of product indicators in latent variable interaction models: post hoc analyses. Psychol Methods. 2014;19(3):444-57.

20. Maslowsky J, Jager J, Hemken D. Estimating and interpreting latent variable interactions: a tutorial for applying the latent moderated structural equations method. Int J Behav Dev. 2015;39(1):87-96.

21. Muthén LK, Muthén BO. Mplus User's Guide. 7th ed. Los Angeles: Muthén \& Muthén; 2012.

22. Jöreskog K, Sörbom D. Lisrel 8: structural equation modeling with the SIMPLIS command language. Lincolnwood: Scientific Software International, Inc.; 1993.

23. Bloemer J, de Ruyter K, Wetzels M. Linking perceived service quality and service loyalty: a multi-dimensional perspective. Eur J Mark. 1999;33(11/12):1082-106.

24. Bollen KA. Structural equations with latent variables. 1st ed. USA: WileyInterscience; 1989.

25. Steiger JH. Structural model evaluation and modification: an interval estimation approach. Multivar Behav Res. 1990;25(2):173-80.

26. www.statmodel.com. Chi-Square difference testing using the Satorra-Bentle scaled Chi-Square. https://www.statmodel.com/chidiff.shtml. Accessed 15 Apr 2019

27. Magelssen M. When should conscientious objection be accepted? J Med Ethics. 2012;38(1):18-21. https://doi.org/10.1136/jme.2011.043646.

28. Pearl J. Graphs, causality, and structural equation models. Sociol Methods Res. 1998;27(2):226-84

29. Kline RB. Principles and practice of structural equation modeling. 4th ed New York: The Guilford Press: Methodology in the Social Sciences; 2016.

\section{Publisher's Note}

Springer Nature remains neutral with regard to jurisdictional claims in published maps and institutional affiliations.

Ready to submit your research? Choose BMC and benefit from:

- fast, convenient online submission

- thorough peer review by experienced researchers in your field

- rapid publication on acceptance

- support for research data, including large and complex data types

- gold Open Access which fosters wider collaboration and increased citations

- maximum visibility for your research: over $100 \mathrm{M}$ website views per year

At $\mathrm{BMC}$, research is always in progress.

Learn more biomedcentral.com/submissions 